\title{
DISTRIBUTION OF GLUCOCORTICOID RECEPTORS IN THE BRAIN OF RAINBOW TROUT (ONCORHYNCHUS MYKISS) : \\ POSSIBLE RELATIONSHIPS WITH THE NEUROENDOCRINE SYSTEMS CONTROLLING REPRODUCTION.
}

\author{
C.A. TEITSMA, I. ANGLADE, T. BAILHACHE, M. TUJAGUE, G. TOUTIRAIS, \\ B. DUCOURET and O. KAH
}

\begin{abstract}
Endocrinologie Moléculaire de la Reproduction, CNRS UPRES-A 6026, Campus de Beaulieu, 35042 Rennes Cedex, France.
\end{abstract}

\begin{abstract}
The distribution of the glucocorticoid receptor (GR) within the forebrain of rainbow trout has been studied by means of in situ hybridization (ISH) and immunohistochemistry (ICC) using probes and antibodies directed against the AB-domain of the rainbow trout GR (rtGR).
\end{abstract}

Both rtGR mRNA and protein exhibited the same pattern of distribution. A strong labelling was observed in all subdivisions of the preoptic nucleus, in the thalamic region and in the mediobasal hypothalamus (nucleus recessus lateralis, nucleus lateralis tuberis). It was notably found that all magnocellular neurons of the nucleus preopticus pars magnocellularis (NPOmc) were positive with both ISH and ICC. Furthermore, numerous cells of the anterior lobe of the pituitary were positively stained.

Double staining studies allowed to identify part of the rtGR expressing cells. At the telencephalic level, it was found that $\mathrm{GnRH}$ neurons frequently express rtGR in vitellogenic females. Virtually all tyrosine hydroxylase (TH) cells in the anteroventral part of the preoptic nucleus (NPOav) were rtGR-positive. In this same area, a colocalization between rainbow trout estradiol receptor ( $r \mathrm{tER}$ ) and $\mathrm{TH}$ has already been documented, indirectly demonstrating that rtER and rtGR are colocalized. The same holds true for the GTH-II cells of the anterior pituitary which express both types of receptors.

These results provide information on the potential sites of cortisol action on the reproductive axis directly at the pituitary level or indirectly on neuroendocrine systems controlling GTH-II secretion, possibly via GR-ER interactions.

\section{DISTRIBUTION DES RÉCEPTEURS AUX GLUCOCORTICOÏDES DANS LE CERVEAU DE LA TRUITE ARC-EN-CIEL (ONCORHYNCHUS MYKISS) : RELATIONS POSSIBLES AVEC LES SYSTĖMES NEUROENDOCRINIENS CONTRÔLANT LA REPRODUCTION.}

\section{RÉSUMÉ}

La distribution du récepteur aux glucocorticoïdes (GR) dans le cerveau de la truite arc-en-ciel a été étudiée par les techniques d'hybridation in situ (HIS) et d'immunocytochimie (ICC) utilisant des sondes et des anticorps dirigés contre le domaine $A B$ du $G R$ de truite (rtGR).

Les sites d'expression de l'ARNm et de la protéine rtGR sont très similaires. Les deux méthodes ont permis de mettre en évidence un marquage au niveau des différentes sousdivisions du noyau préoptique (NPO), en particulier au niveau des neurones 
magnocellulaires (NPOmc). Un fort marquage a également été observé au niveau du thalamus et de l'hypothalamus médiobasal (nucleus recessus lateralis, nucleus lateralis tuberis). De nombreuses cellules du lobe antérieur de l'hypophyse expriment également le rtGR.

Des études de double marquage en ICC ont permis d'identifier la nature des cellules exprimant le rtGR. Les cellules à TH (tyrosine hydroxylase) situées dans la partie antéroventrale du NPO (NPOav), où nous avions précédemment détecté une forte expression du récepteur à l'oestradiol de la truite (rtER), expriment le rtGR. Cette colocalisation apparaît d'autant plus importante que le rtGR et le rtER sont exprimés par les mêmes cellules dans le NPOav. En ce qui concerne l'axe gonadotrope, certains neurones à $\mathrm{GnRH}$ du télencéphale ventral ainsi que des cellules à GTH-II de l'hypophyse ont été mis en évidence comme étant positifs pour le rtGR. De plus, il existe également une colocalisation rtGR/rtER dans ces cellules à GTH-II.

Ces résultats apportent des informations sur les sites d'action du cortisol le long de l'axe reproducteur, indiquant que cette hormone pourrait agir directement au niveau hypophysaire ou au niveau de systèmes neuroendocriniens centraux contrôlant la sécrétion de GTH-II. Par ailleurs, ces modalités d'actions pourraient mettre en jeu des interactions GR-ER.

\section{INTRODUCTION}

In vertebrates, stress has an effect on many functions, in particular immunity, growth and reproduction (WALKER et al., 1997). The stress responses are mediated by corticosteroids, which bind to specific nuclear receptors (FUNDER, 1992). Corticosteroids can be divided into two types : type I, the mineralocorticoids and type II, the glucocorticoids (JOELS and DE KLOET, 1994). In fish, however, it has generally been accepted that both types of functions are exerted by the glucocorticoid cortisol. Each corticosteroid binds to its own receptor class : mineralocorticoid receptors (MR) or glucocorticoid receptors (GR). Nevertheless, corticosterone can bind to both types of receptors according to the circumstances (DE KLOET et al., 1987).

In salmonids, the effects of stress on reproduction have been largely studied. Exposure of rainbow trout (Oncorhynchus mykiss) to incidences of acute stress during reproductive development results in delayed ovulation and reduced egg size in females, significantly lower sperm counts in males and, concerning the progeny of these fish, significantly lower survival rates compared to progeny from unstressed control fish (CAMPBELL et al., 1992). Also female brook trout exposed to acid stress have a delayed ovulation (TAM and PAYSON, 1986 ; MOUNT et al., 1988). Reduced egg size could be due to impaired vitellogenin production and uptake, as it has been shown that rainbow trout exposed to acid stress have lower plasma levels of vitellogenin (ROY et al., 1990). Furthermore, acid stress in brook trout results in adverse effects on carbohydrate metabolism and liver physiology reducing the liver ability to metabolize carbohydrates and synthesize vitellogenin (TAM et al., 1987). Sublethal exposure of Atlantic salmon to cyanide inhibits yolk deposition by suppressing uptake at the ovarian level (RUBY et al., 1987). It is difficult to explain the effects of acid stress on vitellogenin levels and synthesis, because in both rainbow trout (WEINER et al., 1986) and brook trout (TAM and PAYSON, 1986) no significant change in estradiol levels has been reported. It is therefore possible that impairment takes place at a higher level of the reproductive axis as, for instance, low $\mathrm{pH}$ suppresses gonadotropin (GTH) secretion in brook trout (TAM et al., 1990). Rainbow trout subjected to emersion stress have significantly higher plasma cortisol levels than unstressed control fish (CAMPBELL et al., 1992). Also brown trout, which underwent acute handling stress, show a rise in cortisol levels 1-2 hours post-stress (PICKERING et al., 1982). These results indicate that effects of stress in salmonids are, at least in part, mediated by cortisol. Indeed, evidence exists that exogenous cortisol produces inhibitory 
effects on reproduction similar to those reported in fish exposed to stress, for instance in trout (CARRAGHER et al., 1989 ; POTTINGER et al., 1991). Sexually maturing male and female brown trout have smaller gonads, reduced plasma levels of gonadal steroids and a lower pituitary GTH content after cortisol implantation (CARRAGHER et al., 1989). Cortisol treatment of maturing male rainbow trout significantly suppressed plasma GTH levels (CARRAGHER et al., 1989). However, all these data about the effects of stress on reproduction do not provide information about the possible target sites of cortisol at the reproductive axis. In addition, it has been shown in several teleosts that cortisol does not affect ovarian steroidogenesis (PANKHURST et al., 1995), further indicating that higher levels of the reproductive axis are affected by stress.

The cloning of the rainbow trout glucocorticoid receptor (rtGR) (DUCOURET et al., 1995) made it possible to study the distribution of the rtGR and therefore to identify the possible target sites of cortisol action. The distribution of rtGR mRNA can be determined by means of in situ hybridization and that of rtGR protein by means of immunocytochemistry. Previous experiments, using a probe against rtGR in Northern blot analysis, allowed the detection of a single mRNA species of $7.5 \mathrm{~kb}$ out of poly $A^{+}$mRNA prepared from anterior rainbow trout brain (TEITSMA et al., 1997). A study performed by KNOEBL et al. (1996) already demonstrated a single class of high-affinity, low capacity glucocorticoid receptors in the brain of Chinook salmon (Oncorhynchus tshawytscha). Binding and displacement studies for the GRs of rainbow trout (DUCOURET et al., 1995) and Chinook salmon (KNOEBL et al., 1996) showed that the receptors of both species have a high affinity for dexamethasone and cortisol, demonstrating that these are true glucocorticoid receptors.

Glucocorticoid receptors act as ligand dependent transcription factors and are therefore able to regulate the expression of target genes (EVANS and ARRIZA, 1989). For this reason, identification of the phenotype of the cells expressing the rtGR will provide a first indication about the nature of the possible genes involved in cortisol action. To study the nature of the rtGR expressing neurons, we used double immunohistochemical reactions and we focused our attention on the cells implicated in the control of the reproductive axis : GnRH (gonadotropin releasing hormone) and dopamine neurons, and the GTH-II (gonadotropic hormone-II) cells of the pituitary. We also looked at the possible coexistence of rtGR and rtER (rainbow trout estradiol receptor).

\section{MATERIAL AND METHODS}

\section{Animals}

The rainbow trout (Oncorhynchus mykiss) used, were supplied by the INRA fish farm (Le Drennec, Finistere, France) and kept in the laboratory in a recirculating water system at $12-15{ }^{\circ} \mathrm{C}$ under an artificial light regime mimicking the natural photoperiod. The animals were fed a trout diet ad libitum. Only female trout at different vitellogenic stages have been used.

\section{In situ hybridization}

The method for in situ hybridization used has been detailed in TEITSMA et al. (1997).

Briefly, radioactive sense and antisense probes have been synthesized, directed against the $A B$-domains, responsible for transactivation, of the rainbow trout GR. Trout brains were fixed by means of perfusion with $4 \%$ paraformaldehyde (in $0.1 \mathrm{M}$ phosphate buffer) and then embedded in paraffin. The paraffin sections of $6 \mu \mathrm{m}$ were pre-treated with proteinase $K$ to permeabilize them and with acetic anhydride to reduce background labelling. Then, the sections were hybridized with the radioactive probe at $50^{\circ} \mathrm{C}$ overnight. 
After incubation, several washing steps were performed with SSC buffer of different concentrations and RNAse in NTE buffer. To visualize the signal, the sections were dried and covered with llford K5 nuclear track emulsion. After autoradiography for one month and development of the emulsion, the slides were counterstained and analyzed using an Olympus Provis photomicroscope. For all animals, sections were alternately treated with the sense and the antisense probe to ensure specificity of the signal.

\section{Immunocytochemistry}

Two antibodies, produced in rabbit and guinea pig and directed towards the $\mathrm{N}$-terminal part of the rtGR, were used. Their specificity has been checked by Western blotting (TUJAGUE et al., 1998) and immunocytochemistry following preincubation with the antigen (TEITSMA et al., in press).

Immunocytochemistry was executed on frozen sections (14 $\mu \mathrm{m})$ made from trout brains fixed by perfusion with a solution of $4 \%$ paraformaldehyde and $0.2 \%$ picric acid. Prior to incubation overnight with the primary antibody, the sections were pre-treated with $0.5 \%$ milk powder in veronal buffer containing $0.2 \%$ triton $\mathrm{X}-100$ (TX). After exposure to the primary antibody, the sections were rinsed in veronal buffer containing $\mathrm{TX}$ and incubated with the secondary antibody directed against the species of production of the primary antibody. This secondary antibody was labelled with either a peroxidase or a fluochrome.

In the case of a peroxidase conjugated secondary antibody, visualization occurred by using either diaminobenzidine, resulting in a brown precipitate, or the glucose oxidase method according to SHU et al. (1988), resulting in a dark blue precipitate. Fluochrome coupled antibodies could directly be analysed using a fluorescence microscope.

During double staining, two reactions were performed sequentially using different chromogens or fluorophores. We used rtGR antibodies raised in guinea pigs in order to rule out the possibility of cross-reaction of the secondary antibodies with the primary antibodies against $\mathrm{GnRH}, \mathrm{GTH}-\mathrm{Il}$ or rtER, raised in rabbit, and those against TH raised in mouse.

For fluorescence detection of the estradiol receptor (rtER), an amplification procedure using biotinyl tyramide (DUPONT, NEN) has been employed.

Antibody concentrations : anti-rainbow trout glucocorticoid receptor (rtGR ; TUJAGUE et al., in press) $1 / 2000$, anti-salmon gonadotropin releasing hormone (sGnRH ; NAVAS et al., 1995) 1/1500, anti-tyrosine hydroxylase (TH ; LINARD et al., 1996) 1/1000, anti-gonadotropin-II ( $\beta$-GTH-II ; BRETON et al., 1997) 1/1000, affinity-purified anti-rainbow trout estradiol receptor (rtER ; NAVAS et al., 1995)1/50.

\section{RESULTS}

\section{In situ hybridization of the rainbow trout glucocorticoid receptor (rtGR)}

Using in situ hybridization, a specific signal has been observed in the following regions of the rainbow trout forebrain : dorsal telencephalon, ventral telencephalon pars ventralis and pars dorsalis, all levels of the preoptic region, suprachiasmatic nucleus, the medial nuclei of the thalamus, the nucleus lateralis tuberis, the nucleus recessus lateralis, the nucleus posterioris, the nucleus saccus vasculosus and finally the nucleus diffusus lobi inferioris. These results have been summarized in Figure 1. The most remarkable staining was observed at the level of the preoptic nucleus (NPO), where all the magnocellular neurons (NPOmc) were intensively labelled. We also observed a strong labelling of the periventricular layer of the optic tectum. No ISH has been performed at the level of the pituitary. 


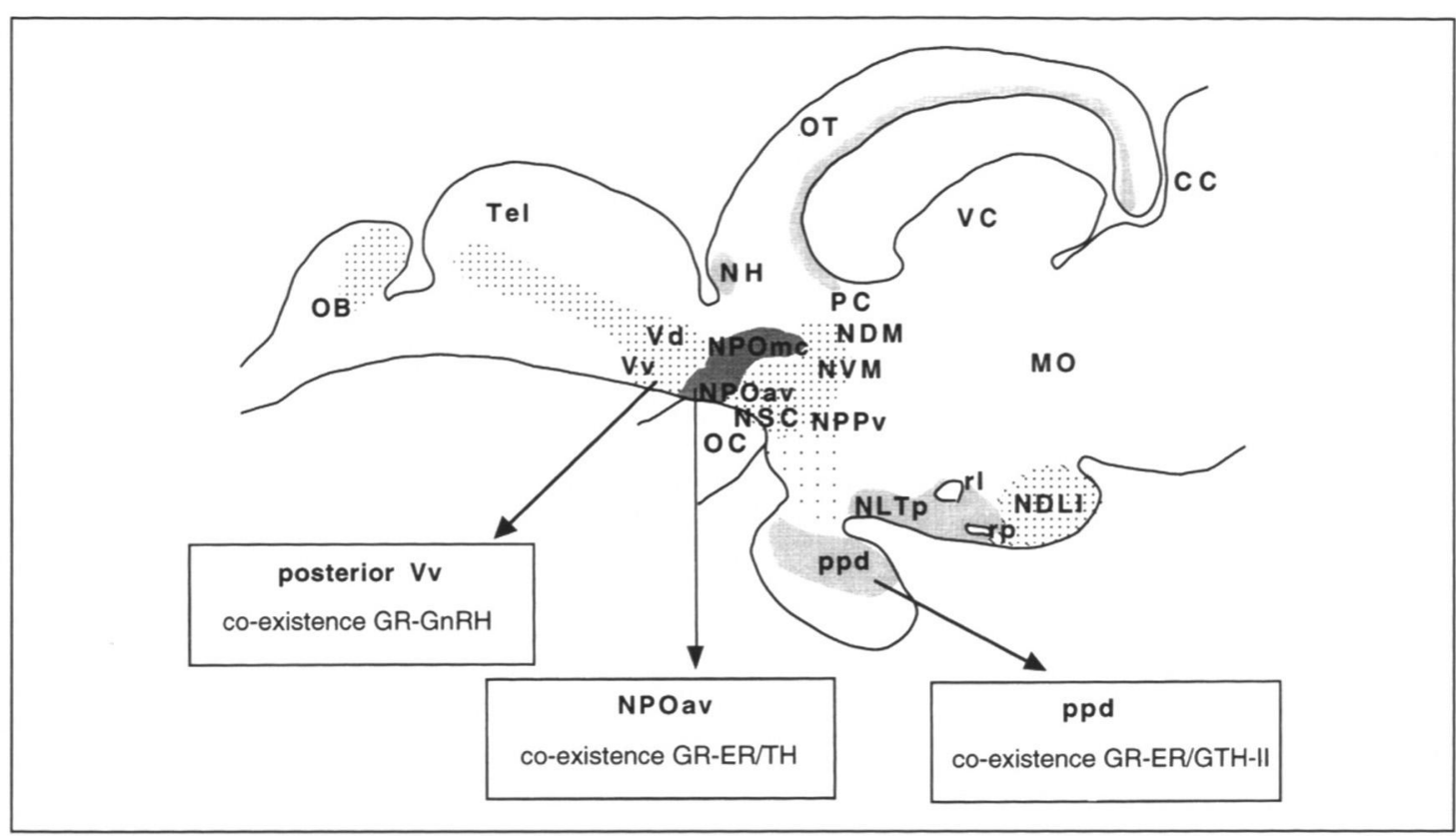

Figure 1

Schematic representation of the distribution of rtGR mRNA and protein expressing cells on a longitudinal section of rainbow trout forebrain. The density of the shaded areas provides an estimate of the density of GR-expressing cells. Boxes show the regions where colocalizations have been observed. $\mathrm{CC}=$ corpus cerebelli ; ER = estradiol receptor ; GR = glucocorticoid receptor ; GnRH = gonadotropin releasing hormone ; GTH-II = gonadotropic hormone-II ; $\mathrm{MO}=$ medulla oblongata $; \mathrm{NDLI}=$ nucleus diffusus lobi inferioris $; \mathrm{NDM}=$ nucleus dorsomedialis thalami ; NH = nucleus habenularis ; NLTp = nucleus lateralis tuberis pars posterioris ; NPOav = nucleus preopticus pars anteroventralis ; NPOmc = nucleus preopticus pars magnocellularis $; \mathrm{NPPV}=$ nucleus posterioris periventricularis ; NSC $=$ nucleus suprachiasmaticus $; \mathrm{NVM}=$ nucleus ventromedialis thalami $; O B=$ olfactory bulbs $; O C=$ optic chiasma $; O T=$ optic tectum $; \mathbf{P C}=$ posterior commissure $; \mathbf{p p d}=$ proximal pars distalis $; \mathrm{rl}=$ recessus lateralis $; \mathrm{rp}=$ recessus posterioris $; \mathrm{Tel}=$ telencephalon $; \mathrm{TH}=$ tyrosine hydroxylase $; \mathrm{VC}=$ valvula cerebelli $; \mathrm{Vd}=$ area ventralis telencephali pars dorsalis ; $V v=$ area ventralis telencephali pars ventralis.

\section{Figure 1}

Représentation schématique de la distribution des cellules exprimant l'ARNm et la protéine rtGR sur une coupe longitudinale du cerveau antérieur de la truite arc-enciel. La densité des points donne une estimation de la densité des cellules exprimant le GR. Les cadres montrent les régions où une colocalisation a été observée. $\mathrm{CC}=$ corpus cerebelli ; $\mathrm{ER}=$ récepteur à l'oestradiol ; $\mathrm{GR}=$ récepteur aux glucocorticoïdes ; GnRH = gonadolibérine ; GTH-II = gonadotropine-II ; MO = medulla oblongata $;$ NDLI = nucleus diffusus lobi inferioris $;$ NDM = nucleus dorsomedialis thalami ; NH = nucleus habenularis ; NLTp = nucleus lateralis tuberis pars posterioris ; NPOav = nucleus preopticus pars anteroventralis ; NPOmc $=$ nucleus preopticus pars magnocellularis $;$ NPPV $=$ nucleus posterioris periventricularis ; $N S C=$ nucleus suprachiasmaticus ; $N V M=$ nucleus ventromedialis thalami $; O B=$ bulbes olfactifs $; O C=$ chiasma optique $; O T=$ toit optique ; $\mathrm{PC}=$ commissure postérieure ; ppd = proximal pars distalis ; $\mathbf{r l}=$ recessus lateralis $; r p=$ recessus posterioris $; \mathrm{Tel}=$ telencephalon ; $\mathrm{TH}=$ tyrosine hydroxylase $; \mathrm{VC}=$ valvula cerebelli $; \mathrm{Vd}=$ area ventralis telencephali pars dorsalis ; $\mathrm{Vv}=$ area ventralis telencephali pars ventralis. 


\section{Immunocytochemistry of rtGR}

The antibody anti-rtGR used, was raised in rabbits by injection of the recombinant protein coupled to glutathione-S-transferase. Visualization of the antibody by means of a secondary peroxidase conjugated anti-rabbit antibody and the glucose oxidase method, revealed a highly specific signal, restricted to the nuclei of the labelled cells. This signal was abolished when the rtGR antibody was preincubated with the fusion protein.

Labelling was observed in the nuclei of the same cells as those already mentioned for in situ hybridization (Figure 1). However, the level of resolution was much better and allowed to obtain a detailed mapping of the rtGR-positive cells. In addition, numerous rtGR-positive cells were also detected in the pars distalis of the pituitary.

The observation of rtGR mRNA and protein in hypophysiotropic areas and pituitary regions, known to be involved in reproduction, prompted us to perform double immunocytochemical studies in these brain areas.

\section{Double immunocytochemistry with rtGR and $\mathrm{GnRH}$, tyrosine hydroxylase, gonadotropin-II and estradiol receptor}

We found out that the best way to perform a double staining with rtGR and GnRH was to use the technique for rtGR as used during the mapping and to use for GnRH a secondary antibody carrying a fluochrome. In this way, we observed that at the level of the posterior part of the ventral telencephalon pars ventralis the majority of the $\mathrm{GnRH}$ neurons in vitellogenic females was positive for the rtGR (Figure 1).

To demonstrate the dopaminergic neurons in the nucleus preopticus pars anteroventralis (NPOav), which are thought to be responsible for the dopaminergic inhibition of GTH-Il release, antibodies against tyrosine hydroxylase (anti-TH) have been used. The anti-TH antibodies have been visualized using the classical diaminobenzidine staining and anti-rtGR according to the previously described method. It was found that in the female trout studied, all TH-positive neurons of the NPOav exhibited a nuclear staining for rtGR (Figure 1).

At the level of the pituitary, a double labelling reaction with rtGR and $\beta$-gonadotropin-II ( $\beta$-GTH-II) has been performed following the same procedure as for rtGR/GnRH. It appeared that the majority of the GTH-II immunoreactive cells was also stained for the rtGR (Figure 1).

Finally, a double immunostaining has been carried out for rtGR and rainbow trout estradiol receptor (rtER). Because the labelling for rtER is too weak for being detected using conventional fluorescence techniques, a biotinyl tyramide amplification system has been used. In addition, the concentration of the guinea pig anti-rtGR antibody has been raised from $1 / 2000$ to $1 / 500$. The primary antibodies were detected by using secondary antibodies having a different fluochrome: FITC for rtGR and Texas red for rtER. Colocalization was observed in two regions (Figure 1) of interest corresponding to the dopaminergic neurons of the NPOav and the GTH-II cells of the pituitary.

\section{DISCUSSION}

The first part of this study consisted of localizing the rainbow trout glucocorticoid receptor (rtGR) in the forebrain of the rainbow trout, Oncorhynchus mykiss. The rtGR mRNA has been localized by means of in situ hybridization (ISH) and the rtGR protein by using immunocytochemistry (ICC). 
Both types of tools, i.e. the probe for ISH and the antibodies for ICC, were directed against the hypervariable $A B$-domains of the rtGR and gave specific results. Comparing the ISH results to those obtained by $I C C$, it can be concluded that the distributional patterns of both rtGR mRNA and rtGR protein are very similar, indicating that the mRNAs are translated into protein. The superposition of the results obtained by the two techniques also reinforces the specificity of the labelling obtained by the two techniques.

Contrary to in situ hybridization, which demonstrates the rtGR mRNA in the cytoplasm, immunohistochemistry allows to determine the subcellular distribution of the mature protein. In our study, we consistently found the labelling to be nuclear. Likewise, the subcellular distribution of GR has been studied in nerve cells of rat brain cortex by PEKKI et al. (1992). These authors found the GR to be nuclear irrespective of the receptors occupancy and they reject the so-called nuclear translocation model, by arguing that any dislocation of the unoccupied receptor towards the cytoplasm is due to the increase of cytoplasmic heat shock protein 90 , which strongly binds the GR after adrenalectomy.

The results of our study show that rtGR is most expressed in the preoptic region and the mediobasal hypothalamus, known to be the major neuroendocrine regions in teleosts projecting towards the pituitary. This observation suggests that cortisol action at the brain level, primarily takes place on neuronal systems involved in the control of pituitary functions. In the course of this study, we observed that the rtGR was expressed in several interesting areas with regard to reproduction. One of these regions was the ventral telencephalon, which contains a part of the $\mathrm{GnRH}$ system extending from the olfactory bulbs towards the pituitary (BAILHACHE et al., 1994 ; NAVAS et al., 1995). Effectively, a double labelling study showed that, at the level of the posterior part of the ventral telencephalon, a majority of the $\mathrm{GnRH}$ neurons expresses the rtGR. Similar results have been obtained in the brain of the rat in which AHIMA and HARLAN (1992) colocalized GR and LHRH in a subset of GnRH neurons. In several studies on the $\mathrm{GnRH}$ secreting cell line GT1-7, it has been shown that the synthetic glucocorticoid dexamethasone is capable of repressing $\mathrm{GnRH}$ gene expression and hence reducing $\mathrm{GnRH}$ secretion (CHANDRAN et al., 1994 ; DEFRANCO et al., 1994 ; CHANDRAN et al., 1996 ; ATTARDI et al., 1997). These results from in vitro experiments are confirmed by an in vivo experiment in rough-skinned newts (Taricha granulosa), during which it appears that stress or injection with corticosterone suppresses LHRH release (MOORE and ZOELLER, 1985). In addition, treatment of castrated rat with dexamethasone prevents the post-castration rise in $\mathrm{GnRH}$ receptors at pituitary level (ROSEN et al., 1988). Furthermore, the promoters of the salmon GnRH genes I and II of the masu salmon (HIGA et al., 1997) appear to contain GREs (glucocorticoid responsive elements), indicating that there exist potential binding sites for GR on the sGnRH gene. Whether these potential binding sites are functional remains to be determined.

The second region of interest was the anteroventral preoptic nucleus (NPOav), where dopaminergic neurons have been localized. These dopaminergic neurons have been demonstrated to contain the estradiol receptor and to project towards the pituitary to inhibit GTH-II secretion (LINARD et al., 1996). In this region, we performed two kinds of double labelling studies: one between rtGR and tyrosine hydroxylase (TH, the rate limiting enzyme of catecholamines) and the other between rtGR and rainbow trout estradiol receptor (rtER). Despite the fact that a triple immunostaining has not been performed, there is convincing evidence that the dopaminergic neurons of the NPOav contain both rtGR and rtER. Indeed, as all dopaminergic neurons of the NPOav express the rtGR and as we have previously shown that $70 \%$ of these cells express the rtER (NAVAS et al., 1995), it is obvious that at least $70 \%$ of the dopaminergic NPOav neurons express both types of steroid receptors. Furthermore, we have formally demonstrated the coexistence of both receptor types in the same cells of the NPOav. The significance of these results is unknown and is open to speculation. It has been suggested that the dopaminergic neurons of the NPOav are 
involved in the negative feedback effect of estradiol on GTH-Il release (KAH et al., 1997). This hypothesis is supported by the fact that in trout an estradiol-dependent dopaminergic inhibitory tone on GTH-II secretion originates from the NPOav and that these dopaminergic neurons express the rtER (LINARD et al., 1995 ; LINARD et al., 1997). Although the molecular targets of estradiol in these cells remain to be demonstrated, it is likely that estradiol via its receptor modulates the activity of these neurons to inhibit GTH-II secretion. Current studies in our laboratory have demonstrated that cortisol inhibits rtER expression in the liver, most likely at the transcriptional level (TEITSMA et al., 1997). Therefore, it is possible that cortisol also interferes with the expression of rtER in the NPOav dopaminergic neurons and the estradiol-dependent inhibitory tone on GTH-II release. Similarly, cortisol could interfere at the level of the pituitary, where we present strong evidence that the GTH-II cells express both rtER and rtGR. As ER is a key factor in the control of GTH-IIB expression (XIONG et al., 1994), it is possible that cortisol interteres via its receptor with the expression of $\mathrm{GTH}-\| \beta$, by reducing the ER availability.

Finally, GR-ER interactions in rainbow trout have already been demonstrated by DUCOURET and LETHIMONIER (unpublished results). When they administered dexamethasone to trout hepatocytes in culture, a $50 \%$ inhibition of the estradiol-stimulated expression of estrogen receptors could be observed. On the other hand, it has been shown that estradiol administration completely reverses the ovariectomy-induced increase in GR mRNA content of the rat anterior pituitary gland (PEIFFER and BARDEN, 1987).

\section{CONCLUSION}

rtGR mRNA and rtGR protein are distributed throughout the neuroendocrine regions of rainbow trout forebrain. Double labelling studies allowed to identify three cellular targets at the level of which cortisol could interfere with the neuroendocrine control of the reproductive axis. Physiological and molecular biology experiments will have to be developed to demonstrate the implication and mode of action of GR in these complex regulatory processes.

\section{ACKNOWLEDGEMENTS}

We would like to thank the CNRS, INRA and European Union (Fair GT 95-2549) for their financial support.

\section{REFERENCES}

AHIMA R.S., HARLAN R.E., 1992. Glucocorticoid receptors in LHRH neurons. Neuroendocrinology, 56, 845-850.

ATTARDI B., TSUJII T., FRIEDMAN R., ZENG Z., ROBERTS J.L., DELLOVADE T., PFAFF D.W., CHANDRAN U.R., SULLIVAN M.W., DEFRANCO D.B., 1997. Glucocorticoid repression of gonadotropin-releasing hormone gene expression and secretion in morphologically distinct subpopulations of GT1-7 cells. Mol. Cell. Endocrinol., 131, 241-255.

BAILHACHE T., ARAZAM A., KLUNGLAND H., ALESTROM P., BRETON B., JEGO P., 1994. Localization of salmon gonadotropin-releasing hormone mRNA and peptide in the brain of Atlantic salmon and rainbow trout. J. Comp. Neurol., 347, 444-454.

BRETON B., SAMBRONI E., GOVOROUN M., WEIL C., 1997. Effect of steroids on GTH-I and GTH-II secretion and pituitary concentration in the immature rainbow trout Oncorhynchus mykiss. Physiology, 320, 783-789. 
CAMPBELL P.M., POTTINGER T.G., SUMPTER J.P., 1992. Stress reduces the quality of gametes produced by rainbow trout. Biol. Reprod., 47, 1140-1150.

CARRAGHER J.F., SUMPTER J.P., POTTINGER T.G., PICKERING A.D., 1989. The deleterious effects of cortisol implantation on reproductive function in two species of trout, Salmo trutta L. and Salmo gairdneri Richardson. Gen. Comp. Endocrinol., 76, 310-321.

CHANDRAN U.R., ATTARDI B., FRIEDMAN R., DONG K.W., ROBERTS J.L., DEFRANCO D.B., 1994. Glucocorticoid receptor-mediated repression of gonadotropin-releasing hormone promoter activity in GT1 hypothalamic cell lines. Endocrinology, 134, 14671474.

CHANDRAN U.R., ATTARDI B., FRIEDMAN R., ZHENG Z.W., ROBERTS J.L., DEFRANCO D.B., 1996. Glucocorticoid repression of the mouse gonadotropinreleasing hormone gene is mediated by promoter elements that are recognized by heteromeric complexes containing glucocorticoid receptor. J. Biol. Chem., 271, 20412-20420.

DEFRANCO D.B., ATTARDI B., CHANDRAN U.R., 1994. Glucocorticoid receptor-mediated repression of $\mathrm{GnRH}$ gene expression in a hypothalamic $\mathrm{GnRH}$-secreting neuronal cell line. Ann. N.Y. Acad. Sci., 746, 473-475.

DE KLOET E.R., RATKA A., REUL J.M.H.M., SUTANTO W., VAN EEKELEN J.A.M., 1987. Corticosteroid receptor types in brain : Regulation and putative function. Ann. N.Y. Acad. Sci., 512, 351-361.

DUCOURET B., TUJAGUE M., ASHRAF J., MOUCHEL N., SERVEL N., VALOTAIRE Y., THOMPSON E.B., 1995. Cloning of a teleost fish glucocorticoid receptor shows that it contains a deoxyribonucleic acid-binding domain different from that of mammals. Endocrinology, 136, 3774-3783.

EVANS R.M., ARRIZA J.L., 1989. A molecular framework for the actions of glucocorticoid hormones in the nervous system. Neuron, 2, 1105-1112.

FUNDER J.W., 1992. Glucocorticoid receptors. J. Steroid Biochem. Molec. Biol., 43, 389394.

HIGA M., KITAHASHI T., SASAKI Y., OKADA H., ANDO H., 1997. Distinct promoter sequences of two precursor genes for salmon gonadotropin-releasing hormone in masu salmon. J. Mol. Endocrinol., 19, 149-161.

JOELS M., DE KLOET E.R., 1994. Mineralocorticoid and glucocorticoid receptors in the brain. Implications for ion permeability and transmitter systems. Progr. Neurobiol., 43, 1-36.

KAH O., ANGLADE I., LINARD B., PAKDEL F., SALBERT G., BAILHACHE T., DUCOURET B., SALIGAUT C., LE GOFF P., VALOTAIRE Y., JEGO P., 1997. Estrogen receptors in the brain-pituitary complex and the neuroendocrine regulation of gonadotropin release in rainbow trout. Fish Physiol. Biochem., in press.

KNOEBL I., FITZPATRICK M.S., SCHRECK C.B., 1996. Characterization of glucocorticoid receptor in the brains of Chinook salmon, Oncorhynchus tshawytscha. Gen. Comp. Endocrinol., 101, 195-204.

LINARD B., BENNANI S., SALIGAUT C., 1995. Involvement of estradiol in a catecholamine inhibitory tone of gonadotropin release in the rainbow trout (Oncorhynchus mykiss). Gen. Comp. Endocrinol., 99, 192-196.

LINARD B., ANGLADE I., CORIO M., NAVAS J.M., PAKDEL F., SALIGAUT C., KAH O., 1996. Estrogen receptors are expressed in a subset of tyrosine hydroxylase-positive neurons of the anterior preoptic region in the rainbow trout. Neuroendocrinology, 63, 156-165. 
LINARD B., BAILHACHE T., CHEGUILLAUME A., ANGLADE I., KAH O., JEGO P., SALIGAUT C., 1997. Control of gonadotrophin release in trout : Estrogen receptor containing dopaminergic neurons and tyrosine hydroxylase expression. Ann. N.Y. Acad. Sci, in press.

MOORE F.L., ZOELLER R.T., 1985. Stress-induced inhibition of reproduction : Evidence of suppressed secretion of LH-RH in an amphibian. Gen. Comp. Endocrinol., 60, 252258.

MOUNT D.R., INGERSOLL C.G., GULLEY E.D., FERNANDEZ J.D., LAPOINT T.W., BERGMAN H.L., 1988. Effect of long-term exposure to acid, aluminium, and low calcium on adult brook trout (Salvelinus fontinalis). Survival, growth, fecundity, and progeny survival. Can. J. Fish Aquat. Sci., 45, 1623-1632.

NAVAS J.M., ANGLADE I., BAILHACHE T., PAKDEL F., BRETON B., JEGO P., KAH O., 1995. Do gonadotrophin-releasing hormone neurons express estrogen receptors in the rainbow trout? A double immunohistochemical study. J. Comp. Neurol., 363, 461-474.

PANKHURST N.W., VAN DER KRAAK G., PETER R.E., 1995. Evidence that the inhibitory effects of stress on reproduction in teleost fish are not mediated by the action of cortisol on ovarian steroidogenesis. Gen. Comp. Endocrinol., 99, 249-257.

PEIFFER A., BARDEN N., 1987. Estrogen-induced decrease of glucocorticoid receptor messenger ribonucleic acid concentration in rat anterior pituitary gland. $\mathrm{Mol}$. Endocrinol., 1, 435-440.

PEKKI A., KOISTINAHO J., YLIKOMI T., VILJA P., WESTPHAL H., TOUHIMAA P., 1992. Subcellular location of unoccupied and occupied glucocorticoid receptor by a new immunohistochemical technique. J. Steroid Biochem. Molec. Biol., 41, 753-756.

PICKERING A.D., POTTINGER T.G., CHRISTIE P., 1982. Recovery of the brown trout, Salmo trutta L., from acute handling stress: A time course study. J. Fish Biol., 20, 229-244.

POTTINGER T.G., CAMPBELL P.M., SUMPTER J.P., 1991. Stress-induced disruption of the salmonid liver-gonad axis. In Reproductive physiology of fish, 1991, SCOTT A.P., SUMPTER J.P., KIME D.E. and ROLFE M.S. eds, Fish Symp. 91 , Sheffield, 114-116.

ROSEN H., JAMEEL M.L., BARKAN A.L., 1988. Dexamethasone suppresses gonadotropin-releasing hormone $(\mathrm{GnRH})$ secretion and has direct pituitary effects in male rats : Differential regulation of $\mathrm{GnRH}$ receptor and gonadotropin responses to GnRH. Endocrinology, 122, 2873-2880.

ROY R.L., RUBY S.M., IDLER D.R., YING S., 1990. Plasma vitellogenin levels in prespawning rainbow trout, Oncorhynchus mykiss, during acid exposure. Arch. Environ. Contam. Toxicol., 19, 803-806.

RUBY S.M., IDLER D.R., SO Y.P., 1987. Changes in plasma liver, and ovary vitellogenin in landlocked Atlantic salmon following exposure to sublethal cyanide. Arch. Environ. Contam. Toxicol., 16, 507-510.

SHU S., JU G., FAN L., 1988. The glucose oxydase-DAB-nickel method in peroxidase histochemistry of the nervous system. Neurosci. Lett., 85, 169-171.

TAM W.H., PAYSON P.D., 1986. Effects of chronic exposure to sublethal pH on growth, egg production, and ovulation in brook trout, Salvelinus fontinalis. Can. J. Fish Aquat. Sci., 43, 275-280.

TAM W.H., BIRKETT L., MAKARAN R., PAYSON P.D., WHITNEY D.K., YU C.K.C., 1987. Modification of carbohydrate metabolism and liver vitellogenic function in brook trout (S. fontinalis) by exposure to low pH. Can. J. Fish Aquat. Sci., 44, 630-635. 
TAM W.H., FRYER J.N., VALENTINE B., ROY R.J.J., 1990. Reduction in oocyte production and gonadotrope activity, and plasma levels of estrogens and vitellogenin, in brook trout exposed to low environmental pH. Can. J. Zool., 68, 2468-2479.

TEITSMA C.A., BAILHACHE T., TUJAGUE M., BALMENT R.J., DUCOURET B., KAH O., 1997. Distribution and expression of glucocorticoid receptor mRNA in the forebrain of the rainbow trout. Neuroendocrinology, 66, 294-304.

TEITSMA C.A., ANGLADE I., TOUTIRAIS G., MUNOZ-CUETO J.A., SALIGAUT D., DUCOURET B., KAH O., in press. Immunohistochemical localization of glucocorticoid receptors in the fore brain of the rainbow trout (Oncorhynchus mykiss). J. Comp. Neurol.

TUJAGUE M., SALIGAUT D., TEITSMA C., KAH O., VALOTAIRE Y., DUCOURET B., 1998. Rainbow trout glucocorticoid receptor overexpression in $E$. Coli : Production of antibodies for western blotting and immunohistochemistry. Gen. Comp. Endocrinol.

WALKER C.D., BODNAR M., FORGET M.A., TOUFEXIS D.J., TROTTIER G., 1997. StresS et plasticité neuroendocrinienne. Médecine/Sciences, 13, 509-518.

WEINER C.S., SCHRECK C.B., LI H.W., 1986. Effects of low $\mathrm{pH}$ on reproduction of rainbow trout. Trans. Am. Fish Soc., 115, 75-82.

XIONG F., LIU D., LE DREAN Y., ELSHOLTZ H.P., HEW C.L., 1994. Differential recruitment of steroid hormone response elements may dictate the expression of the pituitary gonadotropin $\| \beta$ subunit gene during salmon maturation. Mol. Endocrinol., 8, 782-793. 